\title{
Front Matter: Volume 7560
}

, "Front Matter: Volume 7560," Proc. SPIE 7560, Biomedical Vibrational Spectroscopy IV: Advances in Research and Industry, 756001 (10 March 2010); doi: 10.1117/12.858675

SPIE. Event: SPIE BiOS, 2010, San Francisco, California, United States 


\section{PROGRESS IN BIOMEDICAL OPTICS AND IMAGING}

Vol. 11, No. 13

\section{Biomedical Vibrational Spectroscopy IV: Advances in Research and Industry}

Anita Mahadevan-Jansen

Wolfgang Petrich

Editors

23-25 January 2010

San Francisco, California, United States

Sponsored and Published by

SPIE

Volume 7560

Proceedings of SPIE, 1605-7422, v. 7560

SPIE is an international society advancing an interdisciplinary approach to the science and application of light. 
The papers included in this volume were part of the technical conference cited on the cover and title page. Papers were selected and subject to review by the editors and conference program committee. Some conference presentations may not be available for publication. The papers published in these proceedings reflect the work and thoughts of the authors and are published herein as submitted. The publisher is not responsible for the validity of the information or for any outcomes resulting from reliance thereon.

Please use the following format to cite material from this book:

Author(s), "Title of Paper," in Biomedical Vibrational Spectroscopy IV: Advances in Research and Industry, edited by Anita Mahadevan-Jansen, Wolfgang Petrich, Proceedings of SPIE Vol. 7560 (SPIE, Bellingham, WA, 2010) Article CID Number.

ISSN 1605-7422

ISBN 9780819479563

Published by

SPIE

P.O. Box 10, Bellingham, Washington 98227-0010 USA

Telephone +1 3606763290 (Pacific Time) · Fax +1 3606471445

SPIE.org

Copyright (@ 2010, Society of Photo-Optical Instrumentation Engineers.

Copying of material in this book for internal or personal use, or for the internal or personal use of specific clients, beyond the fair use provisions granted by the U.S. Copyright Law is authorized by SPIE subject to payment of copying fees. The Transactional Reporting Service base fee for this volume is $\$ 18.00$ per article (or portion thereof), which should be paid directly to the Copyright Clearance Center (CCC), 222 Rosewood Drive, Danvers, MA 01923. Payment may also be made electronically through CCC Online at copyright.com. Other copying for republication, resale, advertising or promotion, or any form of systematic or multiple reproduction of any material in this book is prohibited except with permission in writing from the publisher. The CCC fee code is 1605$7422 / 10 / \$ 18.00$.

Printed in the United States of America.

Publication of record for individual papers is online in the SPIE Digital Library.

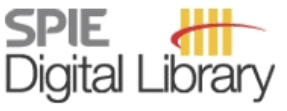

SPIEDigitallibrary.org

Paper Numbering: Proceedings of SPIE follow an e-First publication model, with papers published first online and then in print and on CD-ROM. Papers are published as they are submitted and meet publication criteria. A unique, consistent, permanent citation identifier (CID) number is assigned to each article at the time of the first publication. Utilization of CIDs allows articles to be fully citable as soon they are published online, and connects the same identifier to all online, print, and electronic versions of the publication. SPIE uses a six-digit CID article numbering system in which:

- The first four digits correspond to the SPIE volume number.

- The last two digits indicate publication order within the volume using a Base 36 numbering system employing both numerals and letters. These two-number sets start with 00, 01, 02, 03, 04, $05,06,07,08,09,0 A, 0 B \ldots$. OZ, followed by 10-1Z, 20-2Z, etc.

The CID number appears on each page of the manuscript. The complete citation is used on the first page, and an abbreviated version on subsequent pages. Numbers in the index correspond to the last two digits of the six-digit CID number. 


\section{Contents}

vii Conference Committee

\section{SESSION 1 RAMAN SPECTROSCOPY AND CANCER}

756002 How specific Raman spectroscopic models are: a comparative study between different cancers [7560-03]

S. P. Singh, Advanced Ctr. for Treatment Research and Education in Cancer (India);

K. K. Kumar, M. V. P. Chowdary, K. Maheedhar, Manipal Univ. (India); C. M. Krishna,

Advanced Ctr. for Treatment Research and Education in Cancer (India)

756003 In vivo Raman spectroscopy integrated with multimodal endoscopic imaging for early diagnosis of gastric dysplasia [7560-11]

M. S. Bergholt, W. Zheng, K. Lin, National Univ. of Singapore (Singapore); K. Y. Ho, M. Teh, National Univ. of Singapore (Singapore) and National Univ. Hospital System (Singapore);

K. G. Yeoh, Z. Huang, National Univ. of Singapore (Singapore)

756005 In vivo diagnosis of mammary adenocarcinoma using Raman spectroscopy: an animal model study [7560-02]

R. A. Bitar, Univ. Federal do ABC (Brazil); D. G. Ribeiro, E. A. P. dos Santos, Univ. do Vale do Paraíba (Brazil); L. N. Z. Ramalho, F. S. Ramalho, Univ. de São Paulo (Brazil); A. A. Martin, Univ. do Vale do Paraíba (Brazil); H. S. Martinho, Univ. Federal do ABC (Brazil)

756007 FTIR, Raman, and CARS microscopic imaging for histopathologic assessment of brain tumors [7560-26]

C. Krafft, N. Bergner, C. Matthäus, IPHT Jena (Germany); B. Romeike, R. Reichart, R. Kalff, Friedrich-Schiller-Univ. Hospital Jena (Germany); B. Dietzek, J. Popp, IPHT Jena (Germany) and Friedrich-Schiller-Univ. Jena (Germany)

\section{SESSION 2 RAMAN SPECTROSCOPY AND CELLS}

756008 In situ cell cycle phase determination using Raman spectroscopy [7560-05]

Y. Oshima, Aoyama Gakuin Univ. (Japan) and RIKEN (Japan); T. Takenaka, Aoyama Gakuin Univ. (Japan); H. Sato, RIKEN (Japan) and Kwansei Gakuin Univ. (Japan); C. Furihata,

Aoyama Gakuin Univ. (Japan)

756009 A system for the rapid detection of bacterial contamination in cell-based therapeutica [7560-06]

C. Bolwien, C. Erhardt, G. Sulz, Fraunhofer IPM (Germany); H. Thielecke, R. Johann, Fraunhofer IBMT (Germany); M. Pudlas, H. Mertsching, S. Koch, Fraunhofer IGB (Germany)

7560 0A Surface enhanced Raman spectroscopy for urinary tract infection diagnosis and antibiogram [7560-09]

E. Kastanos, Univ. of Nicosia (Cyprus); K. Hadjigeorgiou, A. Kyriakides, C. Pitris, Univ. of Cyprus (Cyprus) 
7560 OB Raman spectroscopic characterization of single cells [7560-28]

J. Popp, Friedrich-Schiller-Univ. Jena (Germany) and IPHT Jena (Germany); S. Stöckel, S. Meisel, T. Bocklitz, W. Schumacher, M. Putsche, P. Rösch, Friedrich-Schiller-Univ. Jena (Germany)

7560 OC Determination of HER2 amplification status in breast cancer cells using Raman spectroscopy [7560-30]

X. Bi, B. Rexer, C. L. Arteaga, M. Guo, M. Li, A. Mahadevan-Jansen, Vanderbilt Univ. (United States)

\section{SESSION $3 \quad$ IR SPECTROSCOPY}

7560 OD Bird sexing by Fourier transform infrared spectroscopy [7560-10]

G. Steiner, Technische Univ. Dresden (Germany); T. Bartels, M.-E. Krautwald-Junghanns, Univ. Leipzig (Germany); E. Koch, Technische Univ. Dresden (Germany)

$7560 \mathrm{OE}$ In vitro characteristics of a mid-infrared continuous glucose sensor [7560-12] C. Herrmann, C. Vrančić, A. Fomichova, Kirchhoff Institute for Physics, Univ. of Heidelberg (Germany); N. Gretz, S. Hoecker, Univ. Medical Ctr. Mannheim (Germany); A. Pucci, W. Petrich, Kirchhoff Institute for Physics,Univ. of Heidelberg (Germany)

7560 OF Simultaneous observation of ultrafast ligand dissociation and docking-site trapping in heme proteins using upconversion infrared spectroscopy [7560-20]

P. Nuernberger, K. F. Lee, A. Bonvalet, A. Alexandrou, M. H. Vos, M. Joffre, Lab. d'Optique et Biosciences, CNRS, Ecole Polytechnique (France) and Institut National de la Santé et de la Recherche Médicale (France)

\section{SESSION 4 RAMAN SPECTROSCOPY AND NON-CANCER APPLICATIONS}

7560 0G Evaluation of thyroid tissue by Raman spectroscopy [7560-04]

C. S. B. Teixeira, Univ. do Vale do Paraíba (Brazil); R. A. Bitar, Univ. Federal do ABC (Brazil);

A. B. O. Santos, M. A. V. Kulcsar, C. U. M. Friguglietti, Univ. do Vale do Paraíba (Brazil); H. S. Martinho, Univ. Federal do ABC (Brazil); R. B. da Costa, A. A. Martin, Univ. do Vale do Paraíba (Brazil)

$7560 \mathrm{OH} \quad$ Detecting changes during pregnancy with Raman spectroscopy [7560-18] E. Vargis, Vanderbilt Univ. (United States); K. Robertson, A. Al-Hendy, Meharry Medical College (United States); J. Reese, A. Mahadevan-Jansen, Vanderbilt Univ. (United States)

7560 Ol Near infrared Raman spectroscopic study of reactive gliosis and the glial scar in injured rat spinal cords [7560-23]

T. Saxena, B. Deng, Syracuse Univ. (United States); E. Lewis-Clark, K. Hoellger, SUNY Binghamton (United States); D. Stelzner, SUNY Upstate Medical Univ. (United States); J. Hasenwinkel, Syracuse Univ. (United States); J. Chaiken, SUNY Upstate Medical Univ. (United States)

7560 0J Label free investigation of biomolecules on the nanometer scale using tip-enhanced Raman spectroscopy [7560-25]

V. Deckert, Friedrich-Schiller-Univ. Jena (Germany) and IPHT Jena (Germany);

T. Deckert-Gaudig, M. Richter, R. Treffer, X. Lin, IPHT Jena (Germany) 


\section{SESSION $5 \quad$ NEW STRATEGIES IN TECHNOLOGY}

7560 ON Ultra-low spatial resolution Raman mapping using a novel fibre optic probe [7560-29] J. Hutchings, C. Kendall, N. Shepherd, H. Barr, Gloucestershire Hospitals NHS Foundation Trust (United Kingdom); J. Day, Univ. of Bristol (United Kingdom); N. Stone, Gloucestershire Hospitals NHS Foundation Trust (United Kingdom)

\section{SESSION $6 \quad$ NEW STRATEGIES IN ANALYSIS}

756000 Optical fiber bundle coupling errors in Raman spectra: correction via data processing [7560-15]

K. A. Dooley, F. W. L. Esmonde-White, M. D. Morris, Univ. of Michigan (United States)

7560 OP Direct noninvasive observation of near infrared photobleaching of autofluorescence in human volar side fingertips in vivo [7560-24]

B. Deng, C. Wright, E. Lewis-Clark, Syracuse Univ. (United States); G. Shaheen, LighTouch Medical, Inc. (United States); R. Geier, Syracuse Univ. (United States); J. Chaiken, LighTouch Medical, Inc. (United States) and Syracuse Univ. (United States)

\section{POSTER SESSON}

7560 OR Influence of permanent magnetic field on dynamic aqueous glucose absorption [7560-01] X. Zhang, C. M. Ting, W. Zhang, GlucoStats System Pte, Ltd. (Singapore); J. H. Yeo, Nanyang Technological Univ. (Singapore)

7560 OS In vivo Raman spectroscopy of biochemical changes in human skin by cosmetic application [7560-07]

M. G. Tosato, E. P. dos Santos, R. de Souza Alves, L. Raniero, Univ. do Vale do Paraíba (Brazil); P. F. C. Menezes, O. Kruger, C. E. O. Paes, O Boticário Franchising (Brazil); A. A. Martin, Univ. do Vale do Paraíba (Brazil)

7560 OT FT-IR microspectroscopy in rapid identification of bacteria in pure and mixed culture [7560-13]

I. Fontoura, R. Belo, K. Sakane, M. A. G. Cardoso, S. Khouri, M. Uehara, L. Raniero,

A. A. Martin, Univ. do Vale do Paraíba (Brazil)

7560 OU Detecting early stage pressure ulcer on dark skin using multispectral imager [7560-27] D. Yi, L. Kong, S. Sprigle, F. Wang, C. Wang, F. Liu, A. Adibi, R. Tummala, Georgia Institute of Technology (United States)

Author Index 
Downloaded From: https://www.spiedigitallibrary.org/conference-proceedings-of-spie on 25 Apr 2023

Terms of Use: https://www.spiedigitallibrary.org/terms-of-use 


\title{
Conference Committee
}

\author{
Symposium Chairs \\ James G. Fujimoto, Massachusetts Institute of Technology (United \\ States) \\ R. Rox Anderson, Wellman Center for Photomedicine, Massachusetts \\ General Hospital (United States) and Harvard School of Medicine \\ (United States)
}

Program Track Chairs

Tuan Vo-Dinh, Duke University (United States)

Anita Mahadevan-Jansen, Vanderbilt University (United States)

Conference Chairs

Anita Mahadevan-Jansen, Vanderbilt University (United States)

Wolfgang Petrich, Roche Diagnostics GmbH (Germany)

Program Committee

Andrew J. Berger, University of Rochester (United States)

Max Diem, Northeastern University (United States)

Airton Abrahão Martin, Universidade do Vale do Paraíba (Brazil)

Michael D. Morris, University of Michigan (United States)

Dieter Naumann, Robert Koch-Institut (Germany)

Jürgen Popp, Institute of Photonic Technology Jena e.V. (Germany)

Nicholas Stone, Gloucestershire Royal Hospital (United Kingdom)

Session Chairs

1 Raman Spectroscopy and Cancer

Anita Mahadevan-Jansen, Vanderbilt University (United States)

2 Raman Spectroscopy and Cells

Andrew J. Berger, University of Rochester (United States)

3 IR Spectroscopy

Airton Abrahão Martin, Universidade do Vale do Paraíba (Brazil)

4 Raman Spectroscopy and Non-Cancer Applications

Jürgen Popp, Institute of Photonic Technology Jena e.V. (Germany)

5 New Strategies in Technology

Wolfgang Petrich, Roche Diagnostics GmbH (Germany) 
$6 \quad$ New Strategies in Analysis

Nicholas Stone, Gloucestershire Royal Hospital (United Kingdom) 